\title{
"A Ballad Intituled a Pleasant Newe Jigge": The Relationship between the Broadside Ballad and the Dramatic Jig
}

\author{
Roger Clegg
}

\begin{abstract}
Dialogues in song set to popular tunes describes both the broadside ballad and the dramatic jig, and no doubt both forms of popular entertainment are related. If the dramatic jig was a sung-drama featuring props, disguising, and dance, to be acted out on the common stage when a play was done, might the broadside ballad also be a script to be acted out as a dramatic performance? This article considers the relationship between ballad and jig and explores the extent to which the surviving broadside ballads from the seventeenth century may preserve in print vestiges of the stage jig. KEYWORDs: overlap between ballads and dramatic jigs; reconstructions of musical performance; William Kempe; theater afterpieces; solo and dialogue ballads; depictions of courtship
\end{abstract}

WHILE MANY OF THE BALLADS printed on broadsheets in the seventeenth century were undoubtedly purchased only for reading, they also invited performance by those who sold or purchased them in, for example, the alehouse, the milking house, the workplace, or the home. Many surviving broadside ballads contain a dialogue between two characters, or occasionally three or four, that seems to invite dramatic enactment, and some also suggest the use of props, dramatic scenarios, action, and gesture. Additionally, some evoke performance in the form of dance or the vestiges of dance, as Bruce Smith discusses in his essay in this issue. Furthermore, certain ballads contain material intended to be acted out on the amateur or professional stage, or preserve in print traces of the performance of a dramatic jig ${ }^{1}$ - a short, comic, and often

1. Dramatic has been used as a prefix throughout to distinguish such jigs from those that are solely a dance or solely a song (the dramatic jig is also sometimes referred to as the stage jig). This article extends a discussion into the relationship between the dramatic jig and the broadside ballad begun in Singing Simpkin and Other Bawdy Jigs (2014), co-authored with Lucie Skeaping. My thanks to Lucie for sharing her knowledge of ballads and early music.

Pp. 301-322. ( 2016 by Henry E. Huntington Library and Art Gallery. ISSN 0018-7895 | E-ISSN 1544-399x. All rights reserved. For permission to photocopy or reproduce article content, consult the University of Pennsylvania Press Rights and Permissions website, http://www.upenn.edu/pennpress/about/permissions.html. 
bawdy dialogue in song, sometimes featuring dance, slapstick, and disguise. Dramatic jigs were performed at fairs, in villages, taverns, and private houses, and they were featured before, during, or, more regularly, as an afterpiece to plays on London's Tudor and Stuart stages. ${ }^{2}$

By the seventeenth century the term jig had come to have multiple meanings. It could refer to a piece of instrumental music in which, characteristically, the strong beats are divided into groups of three (for example, compound duple [6/8] or triple [9/8] time), or a lively country dance (though no complete jig choreographies survive from the sixteenth century, seventeenth-century references suggest revolving motions, vigorous stepping or hopping, and leaping). But the term had also come to refer to a ballad 3 and a musical-drama:4 for instance, "A Ballad of Kemps Newe Jygge betwixt, a Souldiour and a Miser and Sym the Clown" (1595) describes a dramatic jig for four characters attributed to Will Kemp, clown with the Queen's Men, for which we have a printed script; "Frauncis New Jigge" (ca. 1617) offers a dialogue ballad preserved as a published broadside to be acted out by four singers (fig. 1);5 and Thomas Deloney, in Thomas of Reading (1612), has Cuthbert of Kendal perform a bawdy dialogue ballad in an alehouse with an innkeeper's wife; he calls it "one of my country Iigges to make thee merry." 6

A small number of dramatic jigs have survived in manuscript form, handwritten by a scribe or copied by a scrivener from an earlier source, or in print, published in

2. In the prologue to Christopher Marlowe's Tamburlaine the Great (London, 1590), the audience is told that "From iygging vaines of riming mother-wits, / And such conceits as clownage keeps in pay / Weele lead you to the stately tent of War" (sig. A3r), suggesting that the performance, in 1587, followed the jig. In Ben Jonson's Every Man out of His Humour (London, 1600), Carlo Buffone talks of “a jigge after a Play" (2.1); Jean Bodin complains "now adayes they put at the end of euerie Tragedie (as poyson into meat) a comedie or jigge," in Six Bookes of a Commonweale, trans. Richard Knolles (London, 1606), bk. 6, p. 645; Thomas Dekker laments that "the Sceane after the Epilogue hath beene more blacke (about a nasty bawdy jigge) then the most horrid Sceane in the Play was," in A Strange HorseRace (London, 1613), sig. C4V; James Shirley suggests a surprising shift in the running order of Caroline performances-"Many gentlemen / Are not, as in the dayes of understanding, / Now satisfied without a Iigge, which since / They cannot, with their honour, call for, after / The play, they looke to be serv'd up ith' middle" - in Changes, or Love in a Maze (London, 1631), sig. H2r-v.

3. In William Hemings's The Fatal Contract (London, 1661), the queen says, "Wee'l hear your jig, / How is your ballad titl'd?" (4.3, lines 49-50; sig. G4r). The ballad “The Three Worthy Butchers of the North. I weep, I wail, and Travel much in pain, Now all my youthful days are past, they'l never come again: Once I was a Man, but now alas am none, For all my Companions are from me fled and gone" gives Johnson, the Butcher, the refrain: "Be merry my hearts ... let us sing up a jig" (1672-96), British Library (hereafter BL), Roxburghe 3.30; 4.80, C.20.f.10.80, EBBA 31506. The term jig was also employed in a number of broadside ballad titles, discussed below.

4. The dramatic jig emerged in the late sixteenth century as a natural evolution of dramatic performance that included popular music, balladry, and songs in court farces and morality plays set to dance tunes and sung by players while dancing. London's celebrated clown, Richard Tarlton (d. 1588), a ballad singer and witty extemporizer in rhyme, is often credited as one of the first players to develop song and dance as the conclusion to the afternoon's play.

5. "Frauncis New Iigge, betweene Frauncis a Gentleman, and Richard a Farmer" (1617?), Pepys Library, Magdalene College, Cambridge (hereafter PL), Pepys 1.226-227, EBBA 20102.

6. Thomas Deloney, Thomas of Reading (London, 1612), sig. C4r-v. 


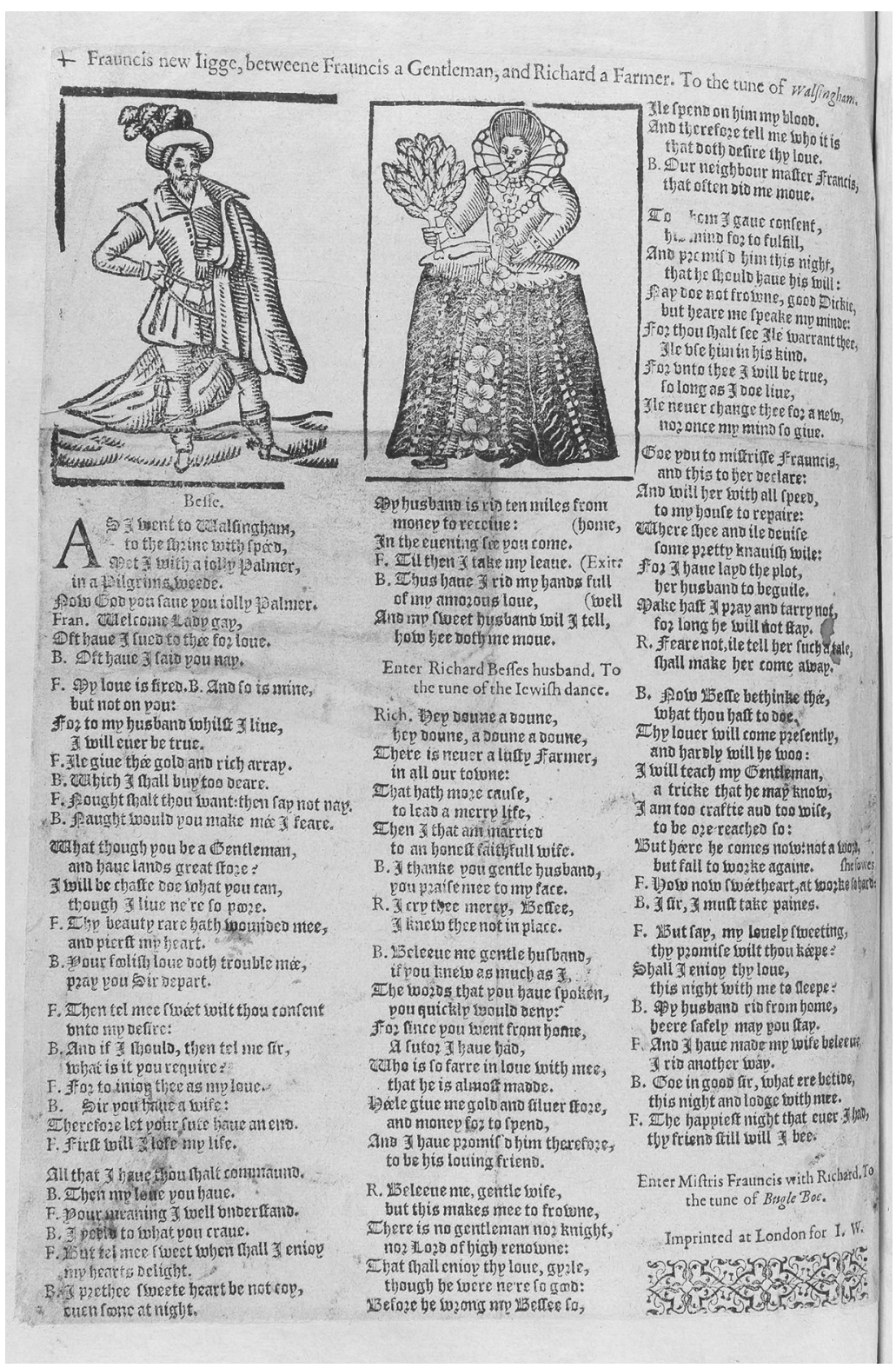

FIGURE 1. "Frauncis New Iigge, betweene Frauncis a Gentleman, and Richard a Farmer" (1617?). Pepys 1.226-227, EBBA 20102. By permission of the Pepys Library, Magdalene College Cambridge. 
pamphlets and bound collections alongside drolls, pastorals, and interludes. 7 Some were published as broadsides along with the great wealth of ballads during the late sixteenth century and throughout the seventeenth, and since the nineteenth century, a number of scholars have, in passing, proposed a relationship between the broadside ballad and dramatic jig. Edmund K. Chambers and William J. Lawrence, who suggest that the dramatic jig began as a dance and developed through the inventions of the stage players into a lyrical and farcical dialogue, further argue that it was connected to the broadside ballad by the common use of popular tunes. ${ }^{8}$ Charles J. Sisson suggests that the dance in fact joined forces with the singing of ballads and was developed into drama in the hands of stage players. ${ }^{9}$ Charles R. Baskervill determines a range of ballad types that probably featured as the basis of dramatic jigs or were certainly fitting material for an afterpiece upon the stage, including gossip songs, conjugal brawls, popular débats, love motives, and wooing (romantic, sentimental, comic or bawdy, even pornographic). ${ }^{10}$ Jack Ashworth and Roger Bagwell suggest that expediency probably led stage players to convert and extend broadside ballads for the stage by assigning the roles to several performers, and adding dance, mime, and blocking for comic effect. ${ }^{11}$ Natasha Würzbach argues that the stage (or dramatic) jig and street ballad could in fact be one and the same thing, whereby the ballad-singer and unemployed actor came together in one person through a competent execution of the ballad-text on stage, observing that "jig texts were also circulated on broadsides, often in shortened versions." 12 Tessa Watt agrees that ballad singing was part of a wide variety of performance forms that included theatrical jigs, but they also constituted a kind of "dramatic performance" in their own right and "printed in dialogue form, sometimes called 'jigs', were (according to their titles) to be acted out at the local and amateur level." 13 Taking these critical stances together, there seems little doubt that the broadside ballad and dramatic jig were closely related. In fact, the reality was probably a mix of all of these propositions: invention and new material mixed with the borrowed and the tried-and-tested, and the performance of a street ballad and the performance of a dramatic jig were at times considered one and the same to writer, spectator, commentator, and critic alike. In contemporary accounts, the dramatic jig seems to have been positioned alongside ballads by those who criticized their tone, content, and form, and when considered against the broadside ballad repertoire, a relationship is evident: both forms were, after all, constructed from the same building blocks of popular and festive song, drama, music, and occasionally dance, and it was

7. For details of these texts, see Clegg and Skeaping, Singing Simpkin.

8. Edmund K. Chambers, The Elizabethan Stage, vol. 2 (Cambridge, 1923), 551; William J.

Lawrence, Pre-Restoration Stage Studies (Cambridge, 1927), 79-80.

9. Charles J. Sisson, Lost Plays of Shakespeare's Age (Cambridge, 1936), 127.

10. Charles Read Baskervill, The Elizabethan Jig and Related Song Drama (Chicago, 1929), 164, ${ }_{167 f f}$. He appends a number of dialogue ballads alongside printed texts and manuscripts of surviving dramatic jigs as related examples of stage texts.

11. Jack Ashworth and Roger Bagwell, Two Elizabethan Stage Jigs (Berkeley, Calif., 1978), 3.

12. Natasha Würzbach, The Rise of the English Street Ballad, 1550-1650 (Cambridge, 1990), 188, 164.

13. Tessa Watt, Cheap Print and Popular Piety, 1550-1640 (Cambridge, 1991), 13, 32. 
this common makeup that sometimes renders them impossible (even unnecessary) to distinguish.

Whether preserved as a manuscript or published in print, increasingly from the end of the sixteenth century, ballads and dramatic jigs either began with, or ended up in, the written word-a medium by which theater and performance preserved themselves and through which they were often (re)constructed-with the performer becoming an agent of writer and of print. Along with plays, both street ballads and dramatic jigs on the stage fed into the shift in agency from performer to author, and from performance text to written form, and back again into performance in the hands (and feet and lungs) of the artist. It is through the written or printed word, therefore, that the vestiges of the performance of ballads and jigs have been preserved. While the broadside ballad and the dramatic jig carved out their own individual niches in an increasingly competitive marketplace-separated, perhaps, by their intended purpose, modes of creation and consumption, and methods of production-they were also connected through common themes, structure and construction, and a reliance on live performance as a vehicle of communication.

By bringing together the number of extant references that refer to both terms, the following survey aims to trace, in more detail than has been available to date, the relationship between singing a ballad and dancing a jig and to suggest how this explains the interrelationship between the dramatic jig and the broadside ballad. As the linguistic application of the terms jig and ballad evolved, so too did their usage in relation to each other. During the sixteenth century, dance songs (the fitting of simple sung refrains to dance tunes) made way for more complex ballads in which the relationship between dance and dance tune was replaced by a privileging of words and narrative. Unlike other forms of storytelling, the dramatic jig's and broadside ballad's primary medium was song. Dramatic jigs and dialogue ballads existed not necessarily as different creatures but along a spectrum of popular entertainment, overlapping in their structure, content, performance style, and as vehicles for slander. Such a relationship can be considered through an analysis of the paratextual features of the surviving dialogue ballads and how they resemble the surviving texts of the dramatic jig. This approach is aided by the ability to search the surviving ballads through the ongoing digitization of broadside ballads in the extensive English Broadside Ballad Archive (EBBA). Why, then, was the life span of the dramatic jig (whose heyday in London's theaters appears to have been between about the 1580 os and the 1630s) shorter than that of the ballad published throughout the seventeenth century; and how far does the surviving broadside ballad repertoire preserve the vestiges of the dramatic jig?

\section{Dance Songs, Ballads, and Jigs}

The combination of singing a ballad and dancing a jig appears first in dance songs of the early sixteenth century before evolving into longer narrative ballads in which dancing became secondary to storytelling. A lyric celebrating the defeat of Edward II's formidable army in the First Scottish War of Independence (1314) is described in 1533 by Robert Fabyan as "songe in daunces"; later, in 1570, John Foxe, in recording "scoffing" 
rhymes written to disparage the English before around 1330, links together "Scottishe gigges and rymes." But the notion that dancing accompanied the lyrics in the fourteenth century appears to have been introduced by Fabyan and Foxe, and perhaps reflects their own experiences at the time of writing in the sixteenth century. ${ }^{14}$ The link between the dancing of a Scottish jig and singing rhymes is confirmed by Alexander Scott's "Ane ballat maid to the derisioun and scorne of wontoun wemen" (ca. 1560) in which Scott euphemistically links "fillokkis" (i.e., giddy or wanton girls) and singing "trolly lolly" (a refrain associated with May celebrations) with "jeigis [jigs] ... up and down" and "frigging fane" (lively movement intended to bring about delight). ${ }^{15}$ Where vigorous singing and dancing occur together, it is most often in the form of short, repetitive dance songs in which the lyrics of the refrain are usually impetus to the steps, intended to drive the dance on, and, in their simplicity, inviting the involvement of as many as will.

Unlike dance songs, longer narrative ballads were intended to be performed by one or a limited number of singers and were primarily vehicles for oral performance rather than dance. Surviving texts or commentaries suggest that either dance steps or song text are combined in different ways: the performer(s) sing and dance simultaneously (in short bursts); the performer(s) sing or dance (where dancing is reserved for in between verses, or at the beginning or end of a song); or the singer delivers the song while others dance. The earliest surviving broadside ballad in which dancing was perhaps synchronous with singing (cited also by Smith in this issue in his discussion of the ballad's origin in dance) is "A Newe Ballade Intytuled Good Fellowes Must Go Learne to Daunce" (1569). ${ }^{16}$ Its text features an instrumentalist plus four dancers, one of whom (in what appears to be a set of caller-instructions, notably in present tense) sings a warning of the need to marry quickly lest someone steal the bride away. Combinations of hopping, jumping, leaping, and revolutions were associated with (although not exclusive to) dancing a jig, and internal evidence evokes such steps-"I must leape and thou must hoppe, / and we must turne all three a: / The fourth must bounce it lyke a toppe." In the ballad “A Mad Kinde of Wooing” (1628), also discussed by Smith, which is set "To the tune of the new dance at the Red Bull" (a playhouse notorious for its rowdy dramatic jigs at this time), Nan, a maid, mocks Will, a country clown, until she is reassured that her lover can "maintain" her well. ${ }^{17}$ In the penultimate verse, Nan finally offers him "both heart and hand" - a moment that perhaps gave the singers the opportunity to conclude the ballad by dancing a lusty jig. Indeed, John Playford's Dancing Master (1698) includes a dance entitled "Red Bull," which is in jig rhythm-

14. Robert Fabyan, The New Chronicles of England and France (London, 1533), pt. 7, 78; and John Foxe, The First Volume of the Ecclesiasticall History (London, 1570), bk. 4, 491.

15. Bannatyne Manuscript MS Adv.MS. 1.1.6, fols. 128r-129r (1568), National Library of Scotland; repr. in The Bannatyne Manuscript, 4 vols. (Glasgow, 1896), 2:363. On the movements in dance of jigs as well as of "jogs" and "jags," see Smith's article in this issue.

16. "A Newe Ballade Intytuled Good Fellowes Must Go Learne to Daunce” (1569); BL, Huth 50 (66).

17. "A Mad Kinde of Wooing, or, a Dialogue betweene Will the simple, and Nan the subtill, With their louing agreement" (1628), PL, Pepys 1.276-277, EBBA 20128. 
that is, where some (but not necessarily all) of the strong beats are divided into groups of three, giving a "bouncy" effect ideal for dancing-and begins with the men taking the women by the hands. Perhaps, then, the jig served as a danced finale. ${ }^{18}$ However, a later broadside, “The Merry Bag-Pipes" (1683-1703), suggests dancing a jig occurred in between the sung verses. ${ }^{19}$ While the tune called for on the broadsheet is "March Boys," the dialogue features a Shepherd who, between each verse, euphemistically "pull'd out his Pipe and began for to play... the Tune of Cater-Bordee." The shepherd is joined by a "Country Damsel" who offers to dance a jig for him ("If thou wilt Pipe Lad, I'll Dance to thee") in jumps and turns, keeping time to the tune's jig rhythm. In the ballad text, dance steps mix with bawdy wooing and double entendre and, while such references may be merely suggestive, it may be that in performance the tune changed from "March Boys" to "Cater-Bordee" (or "Cate of Bardie") for dancing a jig in between the sung verses and providing a contrast to the foursquare rhythm of "March Boys." ${ }^{20}$ The reality is, however, that evidence of the relationship between singing and dancing in broadsides and dramatic jigs remains elusive. ${ }^{21}$

That some broadside ballads and dramatic jigs featured dance to furnish an entrance or an exit, either between sung verses or as a finale, is certain - the extant texts and period commentary on the forms either suggest or tell us as much. ${ }^{22}$ However, of the eight surviving dramatic jig texts dated before the Interregnum, only "Wooing of Nan" (ca.1590-1600), based around a dance contest in which a country fool wins the maid's hand, explicitly calls for episodes of dance. Furthermore, while a great number of songs and broadsides make reference to dancing and dance steps, or print vestiges of abridged or bowdlerized versions of earlier dance songs or circle games, very few are explicit in calling for dance. It seems that as words became more dominant than steps, the relationship between the ballad singer and jig tune was transferred from the feet to the tongue.

18. John Playford, Dancing Master, 10th ed. (London, 1698), 209. The same air is found entitled “The Dam'sells Dance” in Playford's Apollo's Banquet (London, 1670), 75, made up in no small part of "Jiggs and Dances [used] at the Public Theatres."

19. "The Merry Bag-Pipes: or, The Pleasant Pastime betwixt a Jolly Shepherd and a Country Damsel, on a Mid-Summer-Day in the Morning" (1683-1703), PL, Pepys 5.158, EBBA 22423.

20. Thomas Ford's Musicke of Sundrie Kindes (London, 1607), sigs. Mv-M2r, contains the dance tune "Cate of Bardie," which, although in simple quadruple time (that is, $4 / 4$ ), contains several bars in jig rhythm (that is, compound quadruple time, or 12/8). At the bottom of the page in Ford, the tune appears also to be known as "The Queen's Jig": indeed, other concordant sources include "A jigg" in the William Ballet Lute Book (ca. 1590-1610), MS 408, 59, Trinity College Dublin; and the viol duet "The Queenes Jedge" (ca. 1620-30), MSS Mus. Sch. D. 245-7, Bodleian Library. A march followed by a jig wasn't uncommon: for example, the 16th edition of Dancing Master, vol. 2 (London, 1718), 359, contains a piece entitled "King George's March, and the Jigg," in which a march (in 4/4) is followed by a jig (in 6/8).

21. For a more complete picture of the role of dancing in the dramatic jig, see my chapter, "When the play is done, you shall have a Jig or dance of all treads': Danced Endings on Shakespeare's Stage," forthcoming in The Oxford Handbook of Shakespeare and Dance, ed. Lynsey McCulloch and Brandon Shaw.

22. For a detailed discussion on dancing in the dramatic jig in general, and in the surviving texts in particular, see Clegg and Skeaping, Singing Simpkin, 281-88. 


\section{Ballads Sung to Tunes in Jig Rhythm}

As dancing took second place to storytelling involving character interaction and dramatic representation, historical references that connected the term jig to ballad singing occurred increasingly in relation to the tune rather than to dance. More and more, both jig and ballad became terms of contempt to describe songs and dramatic representations in which measure, structure, and rhyme deviated from classical poetic form. From the end of the sixteenth century, it was the text-to-tune relationship rather than the step-to-tune relationship that drew the attention of critics at the time. Defenders of "high" poetic art imagined a divide between classical poetry and the popular rhymes of untrained men, especially ballad makers, whom they considered ignorant and lacking judgment, skill, or understanding of true and proper poetic measure. William Webbe, in his Discourse of English Poetrie (1586), complains about "the vncountable rabble of ryming Ballet makers" who are "compylers of sencelesse sonets, who be most busy, to stuffe euery stall full of grosse deuises ... hobbling vppon some tune of a Northen Iygge." 23 Ballads were written to tunes in a variety of dance rhythms, including jig measures, and were increasingly seen as the province of anyone who cared to put his mind to penning one, which, for many, further lowered the value of the form. By the end of the sixteenth century, both the writing and performing of ballads and dramatic jigs was under attack from those keen to separate the multitude of "rabble rhymesters" from true poets. Fitting words to existing popular tunes (whether specific dance tunes or not) could sometimes create an uneven text-tune relationship despised by purists. As Webbe continues, "Neither is there anie tune or stroke [melody or rhythm] which may be sung or plaide on instruments, which hath not some poetical ditties framed according to the numbers thereof: some to Rogero, some to Trenchmore, to downe right Squire, to Galliardes, to Pauines, to Iygges, to Brawles, to all manner of tunes which euerie Fidler knowes."24

The fear was that the art of poetic verse (which poets like Sidney, Spenser, and Jonson were trying at that very time to elevate) was being eroded by pretenders to poetry who preferred a bawdy rhyme sung to a popular tune. As early as the midsixteenth century, William Baldwin draws attention to the division between those "swete \& mistical balades" that are worthy of worship and those "baudy balades of lecherous loue" that definitely are not; ${ }^{25}$ Thomas Robinson further links the singing of "jigs" with bawdy ballads, when he says that he has heard the nuns at Lisbon "sing him ribaldrous Songs and jigs"; ${ }^{26}$ and Charles Butler complains of the influence exerted on the pastimes of "unstable yunkers" (that is, impressionable youngsters) by ballad makers and dance makers, "the on[e] with obscene and filthy words, the other with immodest and shameless gestures." Music, Butler explains, "[has] a great power over the affection of the mind, by its various moods produced in the hearers," its effects

23. William Webbe, A Discourse of English Poetrie Together, with the Authors Judgment, Touching the Reformation of Our English Verse (London, 1586), sig. Dr.

24. Ibid., sig. F4v.

25. William Baldwin, The Canticles or Balades of Salomon (London, 1549), sig. A3v.

26. Thomas Robinson, The Anatomy of the English Nunnery at Lisbon (London, 1622), 13. 
respected and used by all sorts of people, the "learned and ingenuous, as [well as the] ignorant and barnarous." Of the many moods, the Ionic is "an effeminate and delicate kind of music set unto pleasant songs and sonnets of loov[e], and such like fancies for honest mirth and delight," 27 which Playford warns is derived from the Ionian tribe, whose situation was "full of pleasure, whose plenty and idleness turned their honest mirth into lasciviousness" and made their dancing into a symbol of lewdness and degeneracy. ${ }^{28}$ It is under the Ionic that Butler includes "the infinite multitude of Balads (set to sundry pleasant and delightfull tunes, by cunning and witti Composers) wit[h] Country-dances fitted unto them," 29 and Playford includes "amorous Songs ... and Jigs." 30 References in broadside ballads to dancing a jig (even if such references had become textual or metaphorical, not evoking actual dancing) are most often associated with sexual relationships in the sixteenth and seventeenth centuries. In the young, the focus is on wooing, courtship, and kissing - "hot and hasty, like a Scotch ijgge [sic] (and ful as fantastical)." ${ }^{31}$ In this context, jig becomes a euphemism for sexual activity, wedding nights, and lust in the young, or rejuvenation through sex for both genders. ${ }^{32}$ It is not surprising that such material drew attack and consternation from religious moralists.

Like ballad singing, the sung drama was also under attack from purists (or elitists) who elevated poetry and plays. Thomas Nashe, in Have with You to SaffronWalden (1596), speaks of "a Morall, a Historie, a Tragedie ... with a jigge at the latter end in English Hexameters" - the last actually difficult to achieve as a regular timed meter in English. His description of "English Hexameter" probably makes mocking reference to the dramatic jig, whose line meter stood in contrast to the spoken iambic hexameter (twelve syllables per line) being experimented with in English drama and

27. Charles Butler, Principles of Musik, in Singing and Setting (London, 1636), 130, 2.

28. John Playford, An Introduction to the Skill of Musick (London, 1655), 26. Playford is drawing on satirical images by Roman writers to colour his "Graecian Mood." Horace's Carmina features a nubile young girl who, having perfected Ionian dancing, gives herself over to promiscuous and "unlawful loving" (3.6.21-24); Plautus has his protagonist, Pseudulos, give a drunken and lascivious dance consisting of turns and pirouettes, self-exposure and indecent posturing after "the Ionian fashion" (Pseudulos 5.1); and the professional Ionian dancer in Stichus (lines 766-72) is equated with cinaedus, noted for effeminacy, lasciviousness, and wantonness. L. B. Lawler argues that it was only as Greek civilization fell into decline that the "Ionic dance," attacked by the Roman writers, begins to include decadence, exposure, indecent posturing, and the lifting of the chiton-the long dress worn by both male and female dancers-higher and higher by courtesan-dancers as they performed, "similar to that of

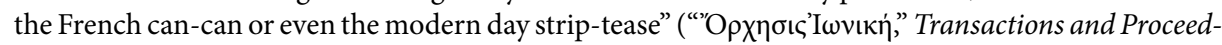
ings of the American Philological Association 74 [1943]: 67).

29. Butler, Principles of Musik, 8.

30. Playford, Introduction to the Skill of Musick, 26.

31. William Shakespeare, Much Ado about Nothing (London, 160o), sig. B4r.

32. For examples, see "The Seamans Lamentation Or, The Captain at the Helm. Shewing how an East-India-Captain in Redderiff Entertained his Boats-Swains Wife, in her Husbands ab-sence, and sent him a Voyage to Cuckold-Shire; where every jovial and loving Seaman may learn Wisdome, and how to be wary, and not to trust his best beloved in his Captains Arms" (1683-85), PL, Pepys 4.194 EBBA 21856; "The Helpless Maidens Call to the Batchelors" (1691), PL, Pepys 5.195, EBBA 22458; "Jone Is as Good as My Lady” (1620), PL, Pepys 1.236-237, EBBA 20108. 
which, in this case, the jig was seen to have followed. 33 The same derision is levied by the Player in The Hogge Hath Lost His Pearle (1614). On reading the jig he has commissioned from Haddit, a stage poet reduced to writing jigs, the Player expresses concern over both the content and the uneven lines of verse:

Pla. Me thinke the end of this staffe is a foote too long.
Ha.
Pla.
Why heare ye, He sings.
And you that delight in truls and minions
Come buy my fowre ropes of hard S[t]. Thomas's onions: 34
Looke you there S[t]. Thomas might very wel have been left
out, besides, hard should have come next the onions.
Fie no, the dismembring of a rime to bring in reason shews
the more efficacy in the writer. ${ }^{35}$

The Player is right: the second line seems a "foote" too long. But Haddit is also right: the playwright's concern for the demands of reason (i.e., meaning) and meter is not the same for the jig writer, whose interest is fitting words to tunes-even if the words form hexameters-often to comic effect. ${ }^{36}$

By the end of the sixteenth century, then, the term jig had come to refer at once to a bawdy song, a lascivious rhyme, a salacious ballad or sung drama, and promiscuous (in the sense of irregular) verse. The true measure of poetry, whether in print or upon the stage, lay in the skill possessed by the learned few; ballad singing and jig making, on the other hand, were within the competence of any drunken hack whose home was the alehouse and who might, as Webbe puts it, hobble upon some country tune or "Northern Jig." Divisions were being drawn, and the dramatic jig was grouped with broadside ballads by those who sought to divide the highbrow and worthy from the lowbrow and worthless.

\section{$\sim$ Ballad-Jigs}

In the same way that the term jig came to be used in the names of some broadside ballads, although seemingly arbitrarily at times, the term ballad came to be used in the Stationers' Register to name dramatic jigs, presumably licensed for publication: "A Merrye and Plesant Newe Ballad. Intytuled Alas the Poore Tynker. / and a new

33. Thomas Nashe, Haue with You to Saffron-Walden. Or, Gabriell Harveys Hunt is Up (London, 1596), sig. R4v.

34. The scansion is: "And you that delight in trulls and minions / Come buy my four ropes of hard [St. Thomas's] onions."

35. Robert Tailor, The Hogge Hath Lost His Pearle (London, 1614), sig. B3r.

36. As Smith observes, the dramatic jig turns to rhyme "most obviously as a renunciation of speech, but also perhaps as an affirmation of speech ... jigs represent a movement away from semantic sense toward something different, toward kinetic sensation... They serve as reminders that speech belongs, after all, to a larger cycle of sounds, a cycle within which semantic sense occupies only a certain segment"; The Acoustic World, 160-61. 
Northerne Jigge" (January 5, 1591) perhaps records a broadside ballad and a jiga combination of song and dance-or a song to a jig tune. "A Ballad of Cuttinge George and His Hostis Being a Jigge" (February 17, 1595) is less equivocal. "A Ballad Intituled A Pleasant Newe Jigge of the Broome-Man" (January 15, 1595, and attributed to William Kemp) and "A Ballad of Master Kempes Newe Jigge of the Kitchen Stuffe Woman" (May 2, 1595) suggest a clown's dramatic jig, since Will Kemp was a wellknown clown and jig dancer. Another ballad that featured Will Kemp, "A Ballad of Kemps Newe Jygge" (October 21, 1595), seems to be "Singing Simpkin," a short dramatic jig featuring four characters involved in a bawdy farce of cuckoldry. In these titles, while the designation ballad clearly refers to song, the designation jig likely acknowledges one or more of the following: the rhythmic characteristics of the tune the words were sung to (although not all ballads described as jigs call for tunes that are in the compound duple or triple form we might refer to as a jig); an accompanying dance (although, however tempting it is to believe that dramatic jigs specialized in the dance form of a jig, evidence indicates that they employed a variety of dances);37 textual content (be it a story based on wooing, or bawdy, or of a lively, merry spirit, or elements of what would come to be termed farce) $; 3^{8}$ and form (either a trifling composition that would take the form of a foolish tale or a funny story - that is, a jest-which could be synonymous with toy, antic, merriment, or trifle). Perhaps the term jig invoked an expectation of all or some of these in the ballad buyer.39

In common with broadside ballads, furthermore, the publication of dramatic jigs was a commercial enterprise profiting authors, compilers, and performers alike. Texts were sold, resold, abridged, and repackaged in numerous ways, with some offering the consumer a "brand" (Kemp's name, for example). The entries in the Stationers' Register of dramatic jigs licensed for publication suggest that occasionally texts moved from the private hands of the stage clowns into the public domain of consumers by way of publication - a way, perhaps, for playing companies to both protect and exploit their investment, or for a performer to lay claim to his repertoire. As in a broadside, such transference of a dramatic jig into a readily available text provided "a framework for performance to exceed," as Richard Preiss points out; that is, the "utility" of jig as text "lay in the pleasure of anticipating what was not yet in it" and could be brought out

37. Donald Lupton, in London and the Countrey Carbonadoed, says, "Most commonly when the play is done, you shal haue a Iigge or dance of all trads, they mean to put their legs to it, as well as their tongs" (London, 1632), 296.

38. Randle Cotgrave, in A Dictionaire of the French and English Tongues, defines French farce as "the Jyg at the end of an Enterlude, wherein some pretie knauerie is acted" (London, 1611), and in Henry Glapthorn's The Lady Mother, Sucket recalls "those playes that I have seene ... with their Jiggs ith tayles of them like your French farces!" (ca. 1635; published in A Collection of Old English Plays, ed. A. H. Bullen, vol. 2 [London, 1882]), 2.1.

39. Richard Priess, Clowning and Authorship in Early Modern Theatre (Cambridge, 2014), 261-62n1o. Priess suggests the ambiguity in naming of items of the Stationers' Register both as ballad and jig "forces us to ask what exactly was the intended use of a printed jig, and whether it differed from that of a ballad," although he doesn't offer us an answer. He also suggests that in describing the same item entered onto the Register as both ballad and jig, "the scribe may not always have cared to discriminate." The absence of the term ballad from some of the titles of jigs may equally have been the wish by a careful scribe to avoid a tautology: a jig was, after all, a sung drama. 
by the consumers in re-performance.40 The compilers of the Wits, a collection of dramatic jigs and drolls, including "Singing Simpkin," which were acted in public and private, at fairs, in the country, halls, taverns, and on mountebanks' stages, in fact recommend their theatrical scripts to amateurs. They urge anyone to "make up a Treatment to his Friends [with] the help of Fidlers and mercenary mimicks." (Those concerned about committing the words to memory, however, are assured that their songs "may almost be acted Extempore, [which] will be abundantly satisfactory.") 41 The contents of published dramatic jigs, like those of broadside ballads, were also aimed at those reading for pleasure and singing alone as much as for those performing together with fiddlers, ballad mongers seeking a crowd, those undertaking long sea voyages with their mates (as companion pieces to share with the rest of the crew), or strolling players for whom "a few ordinary properties is enough to set them up, and get money in any Town in England." 42

\section{$\sim$ Libels}

More sinister was the link between the broadside ballad and the dramatic jig as synonymous with libel-that is, defamation "either by scoffing at the person of another in rhyme or prose, or by personating him, thereby to make him ridiculous." 43 The turn from ballad to dramatic jig was especially feared. In the pseudonymously authored A Quest of Enquirie (1595), Oliver Oat-meale ironically and humorously promises not to inveigh against ballad singers "if they will sing at your windows a new jigge, termed Anie Tripes" about the trimming of "the Tripe-wife" - a well-known woman scammed of both money and pubic hair-and offers "A Iigg for the Ballad-mongers to sing." 44 In the pamphlet, the husband's greatest fear is that the street ballad will be turned into a dramatic jig, his private life dramatized by a satirizing clown. This sort of transformation of ballad material led George Wither to link together "a rime, / a Curtaine Iigge, / a libell, or a ballet." 45 An example of a dramatic jig that featured as part of a libel case brought before the Court of the Star Chamber is "The Libel of Michael Steel" (ca. 1601-2). The jig centered on the alleged illicit relationship of the Yorkshireman Michael Steel and his maidservant, Frances Thorneton, both named characters in the jig (fig. 2). 46

Steel's complaint was that the accused had openly sung and published the jig in the several market towns within the county of York, and had "geven the same to stage

40. Ibid., 147 .

41. Henry Marsh, Wits, or Sport upon Sport (London, 1672), pt. 1, A3v.

42. Francis Kirkman, Wits, or Sport upon Sport (London, 1673), A3v.

43. Collectanea Juridica, ed. Francis Hargrave, vol. 2 (London, 1792), 100.

44. Oliver Oat-meale, A Quest of Enquirie (London, 1595), sigs. A3r-v, Cv-C2v.

45. George Wither, Abuses Stript, and Whipt. Or Satirical Essayes, (London, 1613), bk. 2, satire 3 , sig. Rv, where reference to "a Curtaine Iigge" is to the Curtain Playhouse, infamous for bawdy dramatic jigs.

46. The National Archives (hereafter TNA), Star Chamber 5/S30/16. A second dramatic jig, or libel, also located in the records of the Court of the Star Chamber, is "Fools Fortune" (1621; TNA, STAC 8/250/31), written to defame a local girl for refusing to marry her social inferior and whose motive was to lay claim to her father's estate. 


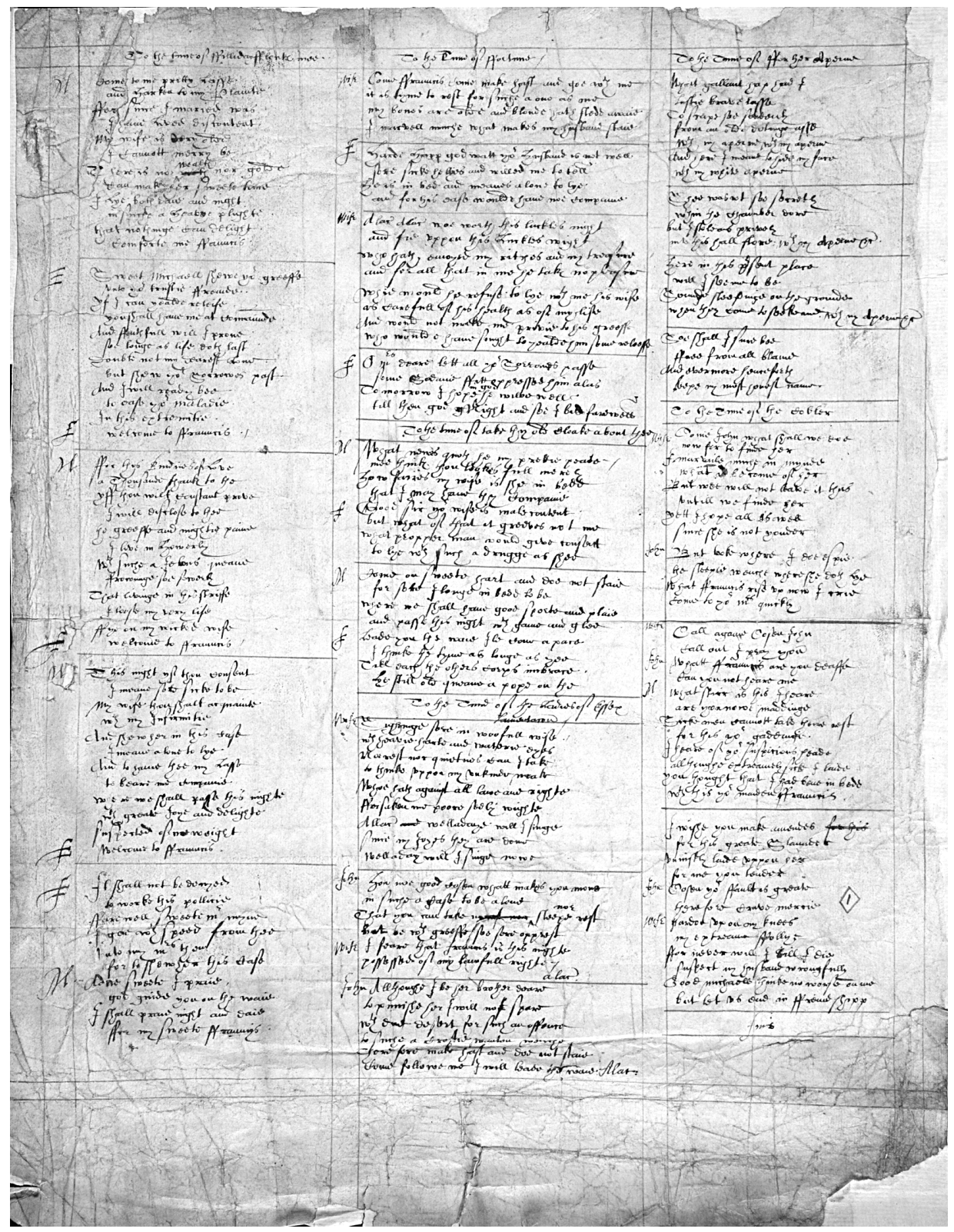

FIGURE 2. "The Libel of Michael Steel" (ca. 1601-2). Reproduced with permission of The National Archives, Star Chamber 5/S30/16. 
players" who "amongest them have att the ending of their playes sunge the same as a jygg to the great scandall of your said subiect and to the utter impayrement of his credytt." 47 Adam Fox suggests that libelers "were obviously adapting to their own purposes, perhaps by just inserting new names, ballads which they knew from printed broadsides." He further indicates "how broadsides might provide the basis for an extemporized song reworked and applied in a specific context," including the public stage. $4^{8}$ The exchange between the street and stage, ballad and dramatic jig, seems to have gone the other way, too: Everard Guilpin condemns the "rotten-throated slaves / Engarlanded with coney-catching knaues, / Whores, Bedles, bawdes, and Sergeants filthily / Chaunt Kemps Iigge," a reference to one of William Kemp's dramatic jigs. 49 Both ballad and dramatic jig were easily constructed by fitting words to popular tunes, which drew concern from those who were suspicious of their makers' intent and the impact of their performance, whether in the theater or on the street.

Such interexchange between street and playhouse suggests that some of the dialogue ballads preserved as broadsides may have had their earlier origins in the dramatic jig. In this interplay of closely knit genres, the broadside ballad emerges as dominant; however, considering the shared influences and purpose of ballads and dramatic jigs (as libels, for instance), it is more than likely that many more of the surviving broadsides preserve material intended originally, or in some early mutation, for dramatic jigs on the stage than has been suggested to date..$^{0}$

\section{N Performing Broadside Ballads}

Such an interrelationship between the stage jig and the surviving broadsides can be further considered through an analysis of the paratextual features of the surviving dialogue ballads and of their resemblance to the surviving texts of the dramatic jig. The ongoing digitization of broadside ballads, in particular by EBBA (University of California, Santa Barbara) and the Bodleian Library (Oxford University), provides the ability to search many surviving ballads using keywords that help to pinpoint potential markers of performativity: a search for "take this," "kiss me," and "here is," for example, unearths in the ballads potential moments of activity that lend themselves easily to

47. The MS is untitled; it was named "Michael and Frances" by Sisson in Lost Plays, 135-40. For the texts, provenance, and analysis of these two libels and related court documents, see "The Libel of Michael Steel," in Clegg and Skeaping, Singing Simpkin, 181-87.

48. Adam Fox, Oral and Literate Culture in England 1500-1700 (Oxford, 2002), 321.

49. Everard Guilpin, Skialetheia, or A Shadow of Truth (London, 1598), satire 5, sig. D5r-v.

50. A number of scholars have suggested dialogue ballads that may have been theater pieces. Rollins (A Pepysian Garland, 173, 207) nominates "A Pleasant New Ballad, both Merry and Witty, That she weth the humours, of the wiues in the City" (1630), PL, Pepys 1.376-377, EBBA 20174; "Newes Good and New" (1623), PL, Pepys 1.210-211, EBBA 20094; and "The Souldiers Farewel to his Love. Being a Dialogue betwixt Thomas and Margaret” (1663-1674), NLS, Crawford.EB.79 3, EBBA 33663 . Baskervill appends all three dialogue ballads to his monograph as examples of dramatic jigs, along with "A Merry Discourse, twixt Him and His Joane, That sometimes did live as never did none, But now at the last she proves very kinde, And doth what heed have her, as here you may finde" (1624-80), BL, Roxburghe 1.82-83, C.20.f.7.82-83, EBBA 30058. The ability to search EBBA using keywords has allowed us to add to these possibilities. 
performance. In this sense, a great number of broadside ballads, whether or not they are designated on the broadsheets as jigs, appear to lock into permanence as printed text the ephemeral vestiges of live performance. If we consider the broadside ballad as a script intended for the creation of performance, it is easy to see how many of these solo or dialogue ballads, printed on broadsheets, might lend themselves to being dramatized.

Beginning with solo ballads (first those designated as jigs, then others), then dialogue ballads for two, three, or four voices (again, first those designated as jigs and then others), the following analyzes the different elements of the surviving broadsides that we might consider to be indicators of performance and of dramatic presentation. I have here taken into account the number of singers (where the presence of two or more lends itself to the performance of dialogue); the apportioning of roles and indicators of characterization (such as naming of stock types); implied use of props; differentiated spaces; dramatic action; and gesture. While a great number of solo ballads might be converted into a sung drama for two or more singers, it is the dialogue ballads intended for two, three, or four singers (whether entitled jig or not) that most resemble the manuscript and printed song dramas of the seventeenth century and that, unlike "Frauncis New Jigge," were not published as broadsides.

The bawdy dialogue ballad "A Pleasant Jigg betwixt Jack and His Mistress" (1675-96?) is intended for a single singer and imagines the changes of speaker and implied action:

\author{
Where's your Master, she cry'd? \\ With a friend, he reply'd; \\ She then void of shame, \\ Said Johnny come kiss me, \\ Sweet Johnny come kiss me, \\ Make much of thy Dame. ${ }^{1}$
}

The song goes on to imagine the arrival of a third character, Johnny's master, who lingers briefly to listen to the wooers, before entering: "And strait did advance, / With fury and Rage, / Like a Fellow Horn-mad, / He fell on the Lad." Such description lends itself to dramatic action even if singly enacted. Where such phrases as "she cried" and "he replied" or "(quoth she)" and "(said he)" are present, we might equally imagine a single singer changing his or her voice to illustrate the different characters, ${ }^{52}$ although it might also suggest that solo ballads were readily adaptable for two or more performers.

51. “A Pleasant Jigg betwixt Jack and His Mistress: Or, The Young Carman's Courage cool'd by the sudden approach, of his Master, who found him too kind to his Mistress" (1675-96?), PL, Pepys 3.14, EBBA 21007.

52. Richard Brathwaite describes a solo ballad-singer who "sings with varietie of ayres (having as you may suppose, an instrumentall Polyphon in the cranie of his nose.) Now he counterfeits a naturall Base, then a perpetuall Treble, and ends with a Countertenure"; Whimzies: or, A New Cast of Characters (London, 1631), 13. 
"The West-Country Jigg" (1672-96?), whose dialogue is in the first person, likewise suggests a single singer who, having introduced the maid, narrates the entrance of her suitor. The narrative features verbs that might easily be acted out, and the third-person narration alters to first-person speaking, which lends the song to being converted into a dramatization by several performers:

\author{
A Young Man hard by \\ This Maid did Espy; \\ Admiring her Beauty, \\ He to her did hye, \\ Quoth he, pritty Saint, \\ It grieves my Heart for \\ to hear your Complaint. \\ What think you of me? \\ I'm active and free; \\ And willing to serve you \\ In every Degree; \\ And by this sweet Kiss, \\ To proffer my Service \\ It is not amiss. 53
}

In the same way, "The Two-Penny Whore" (1678-88) either invites the spectator to imagine the coins ("But yet heres two-pence left, prethee now take it") or implies the use of a theatrical prop. 54 Likewise, the dialogue ballad "Love and Constancy" might easily be sung by a single singer changing voices but, if played by two singers, implies action (kissing) and the passing of props (a ring) alongside bawdy double entendre:

\title{
Then come my own dearest and give me a kiss, now we are united $\mathrm{I}$ count $\mathrm{i}[\mathrm{t}]$ a blis, \\ And here for the present accept of this Ring, ere long I will please thee with a better thing. 55
}

53. "The West-Country Jigg: Or, Love in Due Season. A Longing Maid which had a mind to marry, Complaining was, that she so long should tarry; At length a brisk young Lad did chance to spy her, And liking of her well, resolv'd to try her: And courting her, and vowing to be constant, They there clapt up a bargain in an instant" (1672-96?), BL, Roxburghe 2.506-507, C.2o.f.8.506-507, EBBA 31010.

54. "The Two-Penny Whore; In a Dialogue betwixt a Spend-thrift and a Whore. Or, a Relation of a Two penny Bargain. Of a Spend-thrift proffering two pence to a Whore, Having spent all but that on her before" (1678-88?), BL, Roxburghe 2.486v, C.2o.f.8.486v, EBBA 3098 o.

55. "Love and Constancy Or The true Lovers welcome home from France. Describing of the joy and friendly greeting, Betwixt two Lovers at their happy meeting, By cruel Fate long time they were devided, But to their comfort now they are united, Which makes them to rejoyce beyond expression, As you may finde by both their own confession" (1673-90?), BL, Roxburghe 4.19, C.20.f.10.19, EBBA 30920 . 
Other, more clearly designated two-person dialogue ballads designate roles by indicators such as $M$ or $W$ (that is, Man and Woman, or sometimes Man and Wife), as in "A Mery New Jigge" (1630) between Pegge, a "faire Maid," and Kit, a "Rusticke clowne":

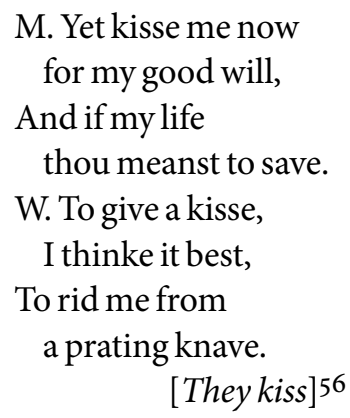

This verse, and that which follows, suggest a before and after the kiss; and if the singers were accompanied by instruments, the music could continue until the stage business was completed. There is also a clear sense of location at the beginning of the ballad"M. Well met faire Maid, / my chifest joy"-and it ends just as clearly in space and time:

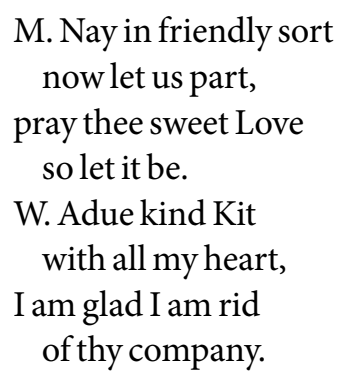

As Pegge exits the real or imagined performance space, Kit, the "Rusticke clowne," remains to deliver to the spectator/audience a brief moral epilogue. This convention, common in broadside ballads, allows the performer license to break the fourth wall of performed drama and to straddle the boundary between stage and audience. He issues a warning to all lovers about the dangers of inconstancy in love, lest "you be served in like kind." 57 Such transitions between, and blurring of, spatial boundaries-the real world of performance and the imagined world of the ballad-lend themselves to stepping onto and off a physical stage, whose exits in the theater were contained by the tiring house. Equally, the ballad "Clods Carroll: or, a Proper new Jigg” (1615-40) establishes an imagined dramatic space within the real-world location of the ballad event by

56. Valentine Hamdultun, "A Mery New Iigge. Or, the pleasant wooing betwixt Kit and Pegge" (1630), PL, Pepys 1.258-259, EBBA 20119.

57. The use of a short moral epilogue spoken directly to the audience as a conclusion to the song is a device also found in some of the surviving dramatic jig scripts; see Clegg and Skeaping, Singing Simpkin, 254. 
announcing a new location ("Man. Now in the Garden / are we well met") and includes implicit action for the singers ("Wom. Come sit thee down all by my side"). 58 The ballad also implies a significant temporal change in its imagined world: the first half is sung prior to marriage, the second half post-marriage. Lastly, the ballad text indicates three locations: the real world of the ballad event (inhabited by the spectators and singers), the imagined location of the characters, and a third external or imagined space of the characters where, at the end of the first part of the ballad, the man "goes off to marry" (a location outside the ballad event and away from the spectator):

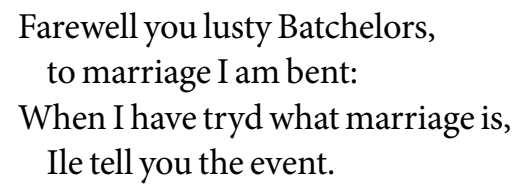

The singer theoretically leaves the performance space of the ballad and then re-enters, having been married - a part ripe for anyone with comic timing to effect the change from naive and lustful gallant into henpecked husband. This is what we might today call pantomime. Ballads, like dramatic jigs, exaggerated the familiar-every member of the audience had a near neighbor just like that, or knew someone (not themselves) just as gullible or just as ignorant. The possible use of props as well as the changes of location and stage business (supported by a recurring tune) that we have seen in the ballad of Pegge and Kit are abundant in the surviving dramatic jig scripts. 59 In blurring physical boundaries of performance, many broadside ballads succeeded in varying ways to function like dramatic jigs, drawing into focus real-world civic, social, and cultural lines of division.

An element that especially extends the action in the performance of ballads into drama is the suggested use of simple props, which transforms imagination into a real object, and what might be a spoken metaphor into a visual symbol. The ballad of "Loving John: Or, Yielding Joan" (1683-1703), as well as a dramatic kiss ("Prithee sweet Joan let us have a kiss") and a great many bawdy references to penis size ("to measure," "pleasure," "length," etc.), appears to call for comic business with a prop such as a sword (perhaps used to underline issues of phallic size and position).

Prithee sweet Jean, take this in thy hand, then you may leave it, if you think fit;

This and myself, is at your command, prithee, sweet Joan, make use of it:

Oh! ne'er say no, but let it go,

for nature will guide it where it should be;

58. "Clods Carroll: or, a Proper new Iigg, to be sung Dialogue wise, of a man and a woman that would needs be married" (1615-40), BL, Roxburghe 1.64-65, C.2o.f.7.64-65, EBBA 30045.

59. For a detailed discussion, see Clegg and Skeaping, Singing Simpkin, 251-54; also, for music used to support stage business, 277 . 
Then prithee love take it, and do not forsake it, until all your senses about do flee. ${ }^{60}$

Dialogue ballads that feature more than two singers in an exchange, thus extending the dramatic grouping, are even more suggestive of dramatic staging. "The Merry Wooing of Robin \& Joan" (1662-92) is sung between three characters: the simpleton Robin, his sweetheart Joan, and his long-suffering mother, who attempts to show her uncouth offspring how to conduct a successful courtship. ${ }^{61}$ The ballad begins with a conversation between mother and son, and then announces the third party, Joan, to the performance space ("But zirrah Mother harke a while / Whoes that that comes so near?"). Gesture is implied when Robin greets her ("virst of all chall take my honds, / And lay them athwart her vace"), and physical action is implied when Robin tells us, "Hark how she comes upon mee now."

Only two dialogue ballads designated on the broadsheets as jigs feature four characters, making them most akin to the dramatic jig. "A Country New Iigge betweene Simon and Susan" (1625?) gives implicit stage directions (fig. 3): Susan (to Simon), "Come goe" (verse 4); Simon (to Susan), "But stay heere comes my Mother" (verse 5); Mother (to Susan), "But stay, here comes your father" (verse 11); and Simon (to Susan/all): “Then let's unto the Parson / and Clerke to say Amen” (verse 17); this ballad concludes with all four personae stepping out of character to sing a short moral epilogue. ${ }^{62}$

The other four-person ballad is "Frauncis New Iigge" (1617?), published as a broadside. Whether uniquely or as the only surviving example, this ballad "jigge" incorporates the full range of theatrical indicators to be found in stage texts of the period: characters' names, apportioned lines, and implicit and explicit stage directions that signal entrances, movement, gesture, and props (see fig. 1). ${ }^{63}$

As well as intertextual performance, there was likely to have been extratextual performance in such ballads as well as in dramatic jigs. While not preserved in the text, such performativity was surely incorporated by any imaginative performer eager to please his audience: an insertion of gesture or pre-prepared lazzi (or comic routines),

6o. "Loving John: Or, Yielding Joan: Being a pleasant Song between two Country Lovers while they were making of Hay" (1683-1703), PL, Pepys 5.222, EBBA 22057. Similar use of a dagger or sword to support innuendo and to imply male sexual arousal is inferred in the jig of "Singing Simpkin" (see Clegg and Skeaping, Singing Simpkin, 253) and was employed by commedia troupes as "lazzo of the rising dagger," recorded in Florence in 1612; see Mell Gordon, Lazzi: The Comic Routines of the Commedia Dell' Arte (New York, 1983), 32.

61. "The Merry Wooing of Robin \& Joan The West-Country Lovers" (1662-92), BL, Roxburghe 2.343, C.2o.f.8.343, EBBA 30787.

62. "A Country New Iigge betweene Simon and Susan, to be sung in merry pastime by Bachelors and Maydens" (1625), PL, Pepys 1.260-261, EBBA 20120.

63. A variant is found handwritten in the manuscript collection of Shirburn Ballads (BL, Add. MS 82932, fols. 216v-220r; ca. 1600-1603) under a slightly different title. The text seems to have been copied into the ballad collection from an earlier source, perhaps text licensed for publication in 1595 . For detailed discussion of this dramatic jig published as a broadside ballad, see Clegg and Skeaping, Singing Simpkin, 119-39. 
impromptu deviations in response to a heckler, or the incorporation of a particular performance skill, no matter how superfluous its relation to the immediate story, were guaranteed approval and delight as well as encouraging repeat audiences or the sale of broadsheets.

It seems possible, even probable, therefore, that a number of surviving broadside ballads demonstrate how pre-Restoration dramatic jigs - whether in their entirety or reduced to the printed limits of the broadside ${ }^{64}$-were preserved on broadsheets in much the same way as some post-Restoration ballads and songs preserve (as we are told in their titles) "an excellent new Play-house Song" from entertainments given at the King's or Duke's playhouses (although such statements may, like the designation jig, have simply been a selling ploy). It seems equally probable that broadside ballads were expanded and embellished to make them suitable as dramatic jigs.

\section{n Conclusion}

Although the surviving dramatic jig texts and broadside dialogue ballads share similar features, the life span of the jig as an afterpiece in the theater was more short-lived than the ballad. Given the elusive nature of the evidence, it is almost impossible to say for certain which of the surviving broadside ballads, if any, may have been featured as a jig after a play. Even though both forms were in the business of making a performance, broadside ballads succeeded stage jigs in part because of their efficient mode of production, distribution, and consumption, which perhaps lent them to different cultural contexts. The dramatic jig was conceived at the hands of a clowning performer whose primary business was to attract paying audiences into the theater (it is perhaps a foolhardy comedian who publishes his best jokes, and we should note that a listing in the Stationers' Register is less proof positive of publication than of a preemptive claim to ownership). As the crowd's taste changed, so the Interregnum closed London's theaters, so that by the 1640 s references to ending the afternoon's entertainment with a jig are increasingly to a bygone era on the stage. ${ }^{65}$ The primary aim of the performance of a ballad was to sell broadsheets, and as more people became literate into the seventeenth century, together with the continuing rise of the middling class, so it became more likely for an individual to buy a ballad sheet for private consumption.

That the dramatic jigs in manuscript form, privately preserved by a few or buried in court documents, have survived less well than a commercially printed and widely published broadside ballad is perhaps unsurprising. Those dramatic jigs that were printed and published have come down to us preserved by the likes of Henry Marsh and Francis Kirkman, collectors of ephemera who considered jigs as separate from ballads and grouped them along with dramatic miscellanies, pastorals, collages of Shakespeare, and "drolls." It may be, then, that the broadside of "Frauncis' New Iigge"

64. Baskervill, The Elizabethan Jig, 166.

65. There is sporadic evidence that plays continued to be performed surreptitiously at the Fortune, the Red Bull, Salisbury Court, and the Cockpit, and that dramatic jigs, along with other entertainments, were performed at the Red Bull during the Interregnum despite edicts from the authorities banning plays. 


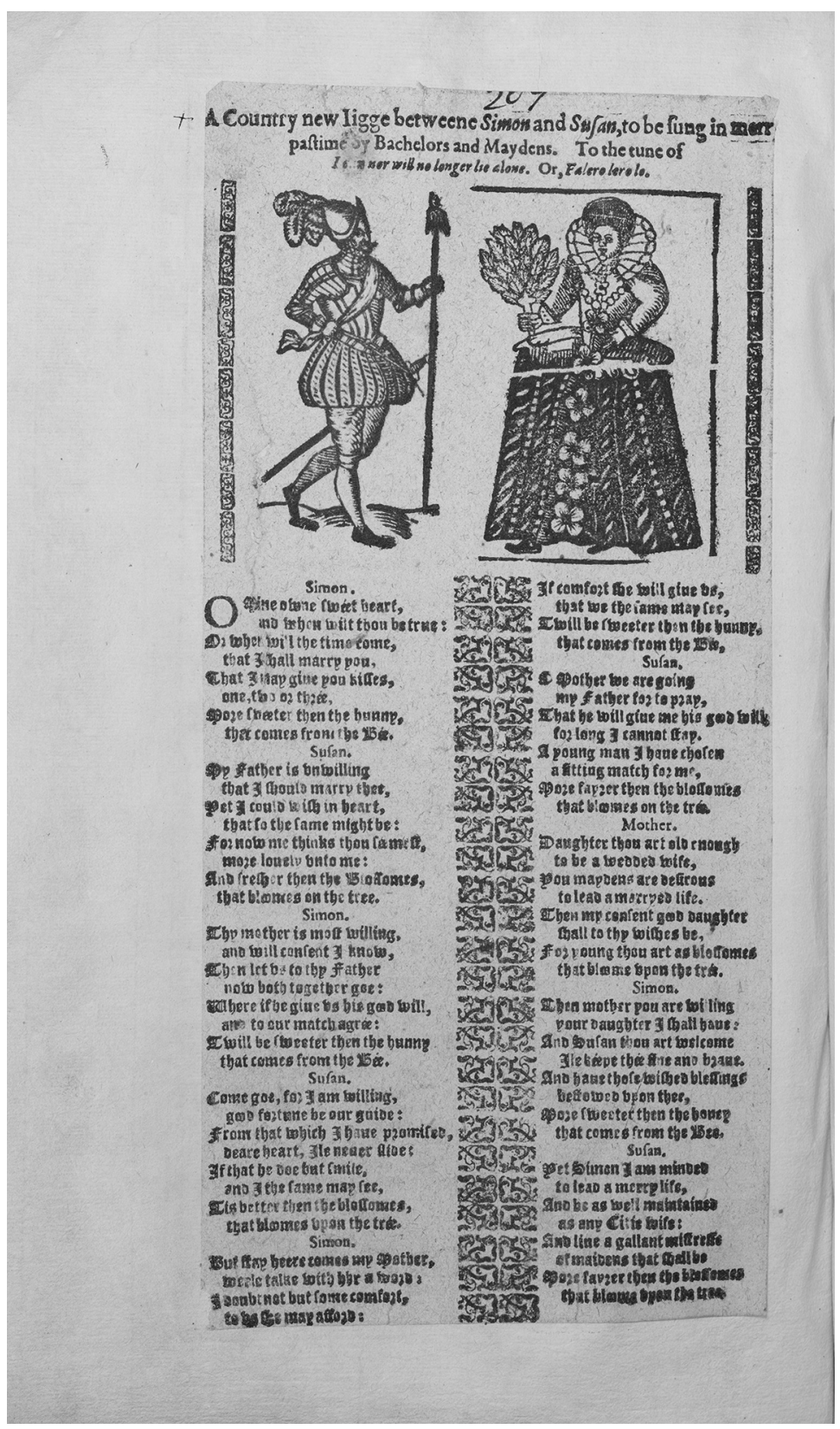

FIGURE 3. "A Country New Iigge betweene Simon and Susan" (1625?). Pepys 1.260-261, EBBA 20120. By permission of the Pepys Library, Magdalene College Cambridge. 
uniquely represents an anomaly in which a dramatic jig was printed and sold as a broadside ballad; alternatively, it may simply be that this is the only example of its kind to have survived.

Given the close connection between the ballad and jig, it seems likely that some of the surviving broadside dialogue-ballads published between the end of the sixteenth through to the mid-seventeenth centuries are examples of dramatic jigs. With the simple addition of a few decorative woodcuts, jigs like the manuscript of "The Libel of Michael Steel" (see fig. 2) could easily have been published as broadsides, but have not survived, to resemble "Frauncis' New Iigge" (see fig. 1) or "A Country New ligge betweene Simon and Susan" (see fig. 3), another printed dialogue-ballad for four singers. With expediency being a driving force, the theaters consumed broadside ballads for live performance and, in the competitive world of broadsheet production, the ever-hungry printers looked to popular theatrical output.

Accounts of jig-making and ballad singing, alongside a reading of the surviving texts of dramatic jigs and broadside ballads, suggest that the vehicle for popular performance ultimately turned through the seventeenth century in the direction of the printed word, motivated by fast-moving proto-capitalist markets in which ballad writers, jig-makers, and their performers borrowed from and exploited features of both genres. Those broadside ballads published after the mid-seventeenth century perhaps best present vestiges of the dramatic jig, when considered "in" performance, and allow us to see how intertwined the broadside ballad and the dramatic jig were, so much so that the two genres at times seem to have become, from the late sixteenth and into the seventeenth century, indistinguishable for the printer, player, spectator, and commentator alike.

Roger CLEgg is Senior Lecturer in Drama Studies at De Montfort University. He has co-authored on the subject of the dramatic jig with Peter Thomson (Studies in Theatre and Performance, 2009) and Lucie Skeaping (Singing Simpkin and Other Bawdy Jigs, 2014). Future publications include "Danced Endings on Shakespeare's Stage" (Oxford Handbook of Shakespeare and Dance, 2017) and a critical history of the jig at Shakespeare's Globe, 1996-2015. 